\title{
THE INTERACTION BETWEEN AROMATASE, METALLOPROTEINASE 2,9 AND CD44 IN BREAST CANCER
}

Fábio Bagnoli ${ }^{1 *}$, Vilmar Marques de Oliveira², Maria Antonieta Longo Galvão da Silva ${ }^{3}$, Giuliana Cássia Morrone Taromaru4 ${ }^{4}$, José Francisco Rinaldi ${ }^{5}$, Tsutomu Aoki ${ }^{6}$ Study conducted at Santa Casa de Misericórdia de São Paulo, São Paulo, SP

\author{
${ }^{*}$ Correspondência: \\ Rua: Cesário Motta Jr. 112- \\ Vila Buarque \\ São Paulo, SP \\ CEP: 012210-020 \\ Phone/ Fax (+55 11) - \\ 32224254 \\ fbagnoli@uol.com.br
}

\begin{abstract}
SUMMARY
Овлестіve. This study intends to verify the expression levels and correlation of aromatase, matrix metalloproteinase 2 (MMP-2), matrix metalloproteinase 9 (MMP-9) and CD44 in ductal carcinoma in situ (DCIS) and infiltrating ductal carcinoma (IDC) when both are found in the same breast.

METHods. One hundred and ten cases were evaluated by tissue microarray (TMA) and immunohistochemically screened with anti-aromatase polyclonal antibodies, anti-MMP-2 monoclonal antibodies, anti-MMP-9 policlonal antibodies and anti-CD44 monoclonal antibodies.

Results. Aromatase was expressed in IDC and DCIS in $63(57.3 \%)$ and $60(67 \%)$ of the cases respectively; MMP-2 was similarly expressed in IDC and DCIS in $15(13.60 \%)$ cases; MMP-9 was positively expressed in IDC and DCIS in $83(75.50 \%)$ and $82(74.50 \%)$ cases, respectively; CD44 was positively expressed in IDC and DCIS in $49(44.50 \%)$ and $48(42.60 \%)$ of the cases, respectively; all of them were highly correlated $(p<0,001)$. The correlation analysis found positive, statistically significant correlation, in IDC between aromatase and MMP-2 $(p<0.001)$ and between aromatase and MMP-9 $(p=0.034)$. Positive correlation between aromatase and MMP-2 $(p<0.001)$ and between MMP-9 and CD44 $(p=0.030)$ were found in DCIS.

Conclusion. These results allow us to conclude that aromatase through local estrogen synthesis in breast tissue plays an important role in breast carcinogenesis, mainly influencing MMP-2 and MMP-9 which are important participants in tumor cell invasion and dependence of their connection to CD44 for action.
\end{abstract}

Key words: Aromatase. Matrix metalloproteinase 2. Matrix metalloproteinase 9. Antigens CD44. Carcinoma ductal breast.

\section{INTRODUCTION}

It is well established that estradiol (E2) plays an important role in the genesis and progression of breast cancer ${ }^{1,2,3}$. Almost $70 \%$ of breast cancer occurs in postmenopausal women and approximately $75 \%$ are estrogen dependent showing that aromatase is very important for carcinogenesis in these women ${ }^{4,5}$.

Estrogen metabolism is mediated by a number of enzymes. Aromatase is a cytochrome P-450 family coded by the CYP19 gene that catalyses the conversion of androstenedione into oestrone (E1) and testosterone into E2 through hydroxylation, oxidation and removes the C-19 carbon and aromatization of the steroid A ring ${ }^{6,7}$. This estrogen synthesis, which is the main form of estrogen production in postmenopausal women, can occur in peripheral tissues, but is found mainly in the local mammary tissue ${ }^{7}$.

A large number of studies have shown that local production of estrogen in breast cancer tissue is higher than in normal breast counterparts due to the presence of very high levels of aromatase $8-12$.

An essential process in forming distant metastases is degradation of the extracellular matrix (ECM) allowing tumor cells to invade local tissue, intravasate and extravasate blood vessels and form new metastatic colonies. This process is primarily

1. Especialista - Médico Segundo Assistente do Departamento de Obstetrícia e Ginecologia da Santa Casa de Misericórdia de São Paulo, São Paulo, SP

2. Doutor em Medicina - Professor Doutor Assistente da Faculdade de Ciências Médicas da Santa Casa de São Paulo e Chefe da Clínica de Mastologia do Departamento de Obstetrícia e Ginecologia da Santa Casa de Misericórdia de São Paulo, São Paulo, SP

3. Doutora em Medicina - Professora Doutora Assistente da Faculdade de Ciências Médicas da Santa Casa de São Paulo e do Departamento de Ciências Patológicas da Santa Casa de Misericórdia de São Paulo, São Paulo, SP

4. Mestre em Medicina - Médica Segundo Assistente do Departamento de Obstetrícia e Ginecologia da Santa Casa de Misericórdia de São Paulo, São Paulo, SP

5. Doutor em Medicina - Professor Doutor Assistente da Faculdade de Ciências Médicas da Santa Casa de São Paulo e do Departamento de Obstetrícia e Ginecologia da Santa Casa de Misericórdia de São Paulo, São Paulo, SP

6. Doutor em Medicina - Professor Doutor Adjunto da Faculdade de Ciências Médicas da Santa Casa de São Paulo e Diretor do Departamento de Obstetrícia e Ginecologia da Santa Casa de Misericórdia de São Paulo, São Paulo, SP 
influenced by activity of tumor secreted proteinases 13,14. Metalloproteinases (MMPs) are the largest class of proteinases in the human genome ${ }^{15}$. MMPs are proteolytic enzymes that can degrade the structural elements of the ECM and release cell-bound inactive precursor forms of growth factors, degrade cell-cell and cell-ECM adhesion molecules and activate others MMPs ${ }^{16}$. The main MMPs involved in breast cancer are metalloproteinase-2 (MMP-2) and metalloproteinase 9 (MMP-9) that have the capacity to degradate type IV collagen which is present on basal membrane and has the function of separating epithelial cells from adjacent stromal ${ }^{17,18}$. The high expression of MMP-2 and MMP-9 in tumors is associated with elevated numbers of distant metastases and poor prognosis 19,20.

Di et al. (2005) ${ }^{21}$, through PCR analysis of breast cancer tissues, found a positive correlation between aromatase, MMP-2, and MMP-9 $(p<0.01)$. Lu et al. (2007) ${ }^{22}$ demonstrated a positive correlation between aromatase, MMP-2, and MMP-9 in breast cancer tissues positive for hormonal receptors $(p<0.05)$.

CD44 is a broadly distributed transmembrane glycoprotein that plays a critical role in a variety of cellular behaviors, including adhesion, migration, invasion and survival. CD44 mediates cell-cell and cell-matrix interactions a primarily through its affinity for hyaluronic acid (HA), a glycosaminoglycan constituent of extracellular matrices, but also potentially through its affinity for other ligands ${ }^{23}$. Okamoto et al. (2002) ${ }^{24}$ showed increased levels of soluble CD44 in plasma from patients with some tumors, reflecting the increase in proteolytic activity and matrix remodeling that is associated with tumor growth and metastasis. Abraham et al. (2005) ${ }^{25}$ found a relation between breast cancer cells that express CD44 and a greater incidence of metastasis.

Some studies have shown that CD44 glycoprotein acts as a docking site for MMP-9 on the cell surface and demonstrated that CD44 and cross-linking leads to an enhanced level and relocation of MMP-9 in human breast tumor cells accompanied by increased tumor invasion and metastasis $26-28$.

\section{Objective}

This study intends to verify the expression levels and correlation of aromatase, MMP-2, MMP-9 and CD44 in ductal carcinoma in situ (DCIS) and infiltrating ductal carcinoma (IDC) when both are found in the same breast.

\section{Methods}

\section{Patients}

We selected one hundred and ten patients surgically treated for breast cancer from the Mastology Clinic of the Obstetrics and Gynecology Department of Santa Casa Hospital between August 2002 and January 2008. Only patients with infiltrating ductal carcinoma and ductal carcinoma in situ in the same surgical specimen were included. This was a cross sectional study approved by the Ethics Committee.

\section{Histopathology and Tissue Microarray Immunohistochemistry}

After study of macroscopic specimens, selected fragments were dehydrated in ethanol, cleared by xylene and embedded in paraffin for preparation of the blocks. The blocks were cut by using a microtome calibrated for $4 \mathrm{~mm}$ thick slabs. The histological sections were stained with hematoxylin and eosin (HE) and read using a light microscope.

DCIS was classified according to presence or absence of comedonecrosis in comedocarcinomas and non-comedocarcinomas. Criteria proposed by Dabbs et al. (1993) ${ }^{29}$ and Elston and Ellis (1991) ${ }^{30}$ were used for classification of DCIS and IDC using nuclear and histological grades, respectively.

Cases with IDC and adjacent DCIS were selected for preparation of the tissue microarray (TMA). Two regions from each histological type were selected for composing the microarray, thus, each case was represented by four areas, two from DCIS and two from IDC from the same patient, comprising a total of 440 regions for analysis.

The expression of aromatase, MMP-2, MMP-9, and CD44 was evaluated by immunohistochemistry analyses using specific antibodies detected by use of the chromogenic substrate diaminobenzidine. The sections were counter stained with Harris hematoxylin, followed by dehydration and mounting in Entellan with cover slips. The primary antibodies used in immunohistochemistry reactions were: rabbit polyclonal antibody anti-aromatase (MCA2077 Serotec Inc.), mouse monoclonal antibody anti-MMP-2 (Mob312 DBS), rabbit polyclonal antibody anti-MMP-9 (A0150 Dako) and mouse monoclonal antibody anti-CD44 (M7082 Dako) in the dilutions 1/70, 1/150, 1/600 and $1 / 200$, respectively.

Evaluation of aromatase, MMP-2, MMP-9 and CD44 - expression.

Expressions of aromatase, MMP-2, MMP-9 were evaluated with scores, by two independent examiners.

We used the same criteria employed by Oliveira et al. (2006) ${ }^{31}$ for analysis of aromatase: score 0: no stained cells observed; score 1: cytoplasm and cell membrane stained diffusely and weakly (it should have at least $10 \%$ of stained cells with strong intensity); score 2: cytoplasm granular staining of the cell membrane and moderate to strong in $10-90 \%$ of cells; score 3 : more than $90 \%$ of cells stained with strong intensity.

To classify the immunohistochemical expression of MMP-2, MMP-9 and CD44 we used the same criteria used by Ellis et al. (2006) $^{31}$ : score 0 and 1 : less than $10 \%$ cells stained, score 2 : less than $30 \%$ of cells weakly stained or strong incomplete staining, score 3: more than $30 \%$ of cells strongly and completely stained.

We used the same criteria as Ristimäki et al. (2002) ${ }^{33}$ and Oliveira et al. (2006) $)^{31}$ to classify the immunohistochemical expression as positive or negative, considering 0 and 1 as negative and 2 or 3 as positive.

\section{Statistical analysis}

The correlation between aromatase, MMP-2, MMP-9 and CD44 was assessed according to the Spearman correlation. The Chi-Square test was used to analyze nuclear grade, histological grade, age group, tumor size, lymph node status, and hormonal status. We set $5 \%$ as the rejection level for the null hypothesis for all parameters evaluated ${ }^{34}$. All data were analyzed by the statistical program SPSS ${ }^{\circledR}$ (Statistical Package for Social Sciences) version 17.0 for Microsoft Windows. 


\section{RESULTS}

The aim of our study was to assess the correlation between aromatase, MMP-2, MMP-9 and CD44 levels in ductal carcinoma in situ and infiltrating ductal carcinoma when both are present in the same surgical specimen. Moreover, an analysis was made to verify if there was any relation between the expression of these biomarkers and age (younger or older than 50 years), tumor size (less than or equal to $2 \mathrm{~cm}$ or more than $2 \mathrm{~cm}$ ), histological grade, nuclear grade, axillary lymph node and hormonal status. Age at diagnosis ranged from 26 to 90 years with a mean age of 56.4 years, with a standard deviation of 12.81 , and median of 55 years.

\section{Evaluation of Aromatase expression}

One hundred and ten cases were evaluated by immunohistochemistry with scores attributed from zero to three, according to the intensity and number of stained cells. Aromatase expression was positive in 63 cases (57.3\%) in DCIS and positive in 67 cases $(60 \%)$ in IDC showing a high correlation ( $p<0.001$ ) (Table 1). There was no statistically significant difference when the expression of aromatase with histological grade, nuclear grade, age, axillary lymph node status and hormonal status was analyzed.

\section{Immunoreactivity to MMP-2, MMP-9 and CD44}

MMP-2 expression was positive in 15 IDC and DCIS cases (13.60\%); MMP-9 was positive in 83 IDC cases $(75.5 \%)$ and 82 DCIS cases (74.5\%); CD44 was positive in 49 IDC cases (44.5\%) and $48 \mathrm{DCIS}$ cases (43.6\%). When performing statistical analysis a high correlation was found between the three

\section{Table 1 - Immunohistochemical expression of aromatase, MMP-2, MMP-9 and CD44 in Invasive ductal carcinoma (IDC) and Ductal carcinoma in situ (DCIS) on 110 cases}

\begin{tabular}{lc}
\hline Biomarker & Absolute number (\%) \\
\hline Aromatase & $63(57.3 \%)$ \\
idc & $67(60 \%)$ \\
dcis & \\
MMP-2 & $15(13.60 \%)$ \\
Idc & $15(13.60 \%)$ \\
dcis & \\
MMP-9 & $83(75.50 \%)$ \\
idc & $82(74.50 \%)$ \\
dcis & \\
CD44 & $49(44.50 \%)$ \\
Idc & $48(42.60 \%)$ \\
dcis & \\
\hline
\end{tabular}

idc = invasive ductal carcinoma; dcis = ductal carcinoma in situ; MMP-2 = matrix metaloproteinase 2; MMP-9 = matrix metaloproteinase 9 biomarker expressions in IDC and DCIS ( $p<0.001$ ). As in the analysis of aromatase, there was no statistically significant difference when the expression of these biomarkers with histological grade, nuclear grade, age, axillary lymph node status and hormonal status was analyzed. (Table 1 )

\section{Correlation between the expression of aromatase, MMP-2, MMP-9 and CD44}

When only IDC regions were considered, a statistically significant positive correlation was found between aromatase and MMP-2 $(p=0.01)$ and between aromatase and MMP-9 $(p=0,034)$. When only the DCIS was evaluated the statistical analysis showed a statistically significant positive correlation between aromatase and MMP-2 $(p=0.001)$ and between MMP-9 and CD44 ( $p=0.03)$. (Table 2)

There was no statistically significant correlation when the expression of aromatase, MMP-2, MMP-9 and CD44 with histological grade, nuclear grade, age, axillary lymph node status and hormonal status was analyzed.

\section{Discussion}

The estrogen function in all phases of breast carcinogenesis is well established. It is found in women of reproductive age and also in post-menopausal ${ }^{1,3}$. The great difference between these two phases of life is that in postmenopausal women extra-ovarian aromatase plays a fundamental role in the estrogen synthesis ${ }^{(7,12)}$.

The peripheral conversion of androgens to estrogens occurs in the adipose tissue, muscle, skin and also in the breast tissue itself and especially in the latter, significant enhancement of conversion due to higher levels of aromatase expression is associated with malignant changes 10,35,36.

In our study we detected aromatase expression, by immunohistochemistry, in $57.3 \%$ of IDC cases and in $60 \%$ of DCIS cases showing a significant correlation $(p<0.01)$. These results agree with the theory that high aromatase expression in tumor epithelium favors tumor formation, especially when aromatase expression is more frequent in DCIS than IDC disclosing the fundamental role of this enzyme in the initial phases of carcinogenesis. Others authors found similar results ${ }^{37,31,35}$.

The high expression of aromatase in our study corroborates the finding of Bulun et al. (2004) ${ }^{11}$, where in normal breast tissue, promoter I. 4 acts while promoters I.3 and II act minimally. In breast cancer tissues they verified the action of promoter I.4 whereas 1.3 and II were extremely higher, and the action of promoter 1.7 , resulted in high estrogen concentration.

In relation to the nuclear grade our results are similar to those found by Hudelist et al. (2008)12, who evaluated 96 samples of DCIS, and 104 samples of DCIS and IDC in the same samples. They found that in DCIS there was no statistically significant difference in aromatase expression between high, moderate and low grade tumors. However Silva et al. (1989) ${ }^{38}$, differently, found higher aromatase expression in nuclear grade III $(p=0.03)$.

Some studies have evaluated prognosis of patients that present higher aromatase expression; Silva et al. (1989) ${ }^{38}$ showed that higher aromatase expression correlates with lower disease free survival $(p<0.05)$. Eppenberger et al. $(2001)^{39}$ found that women with high aromatase expression in breast cancer have increased 
THE INTERACTION BETWEen AROMATASE, METALLOPROtEINASE 2, 9 AND CD44 IN BREAST CANCER

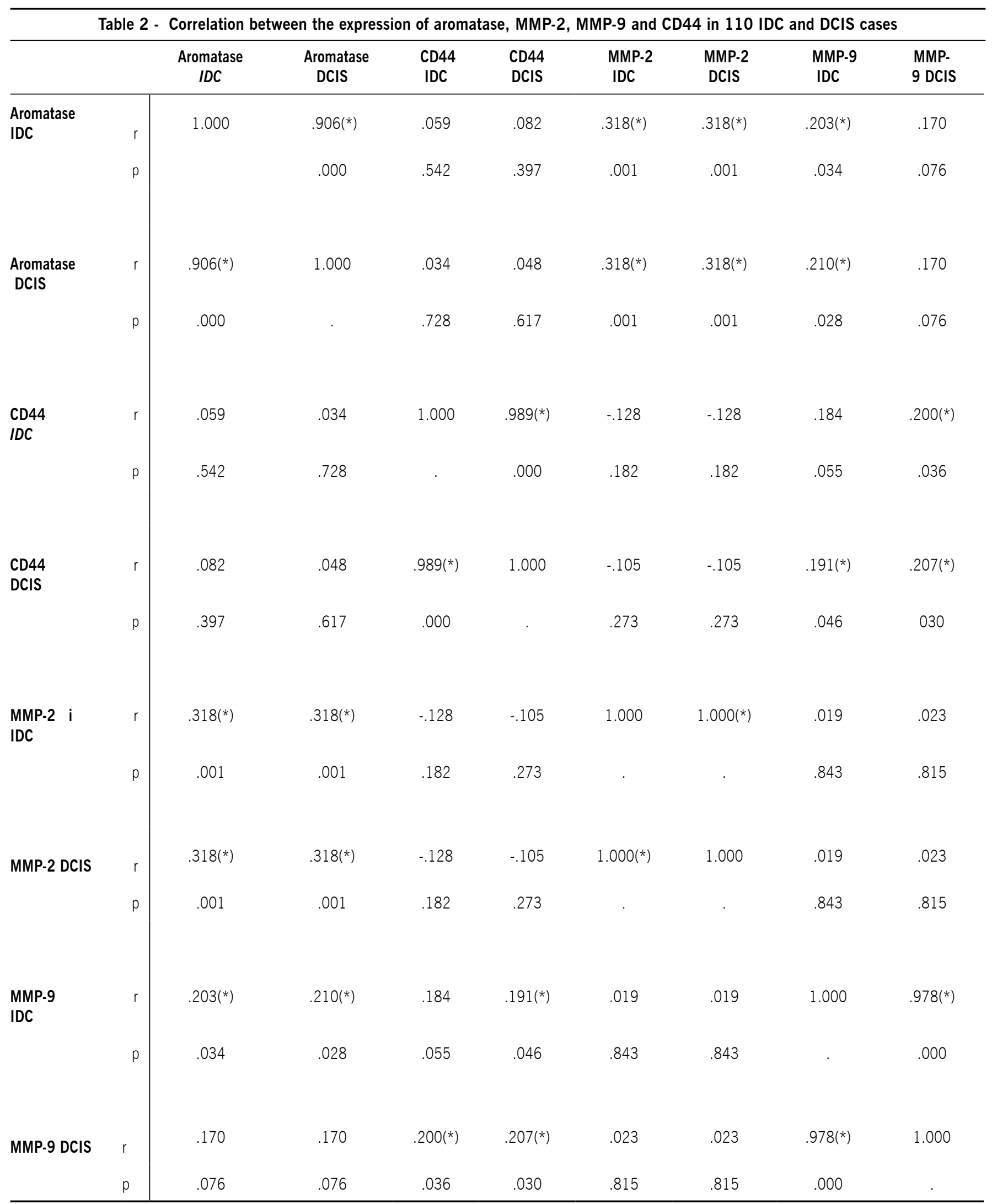

(*) Statistically significant correlation $\mathrm{p}<0.05$. Statistical test: Spearman correlation; $\mathrm{r}=$ correlation coefficient; IDC = invasive ductal carcinoma; DCIS = ductal carcinoma in situ; MMP-2 = matrix metalloproteinase 2; MMP-9 = matrix metalloproteinase 9 
risk of relapse and death $(p<0.05)$. Lu et al. $(2007)^{22}$ in the univariate survival analysis showed that aromatase is significantly and positively associated with decreased overall survival (OS) $(p=$ 0.04 ) in the estrogen receptor (ER) and/or progesterone receptor (PR), positive patients (10 year OS $100 \%$ for the aromatasenegative group compared with $85.1 \%$ for the aromatase-positive group). However, in the multivariate survival analysis, we did not find this association to be significant ( $p>0.05)$. In the ER and PR negative cases, there were no significant OS differences between aromatase negative and aromatase positive patients in either univariate or multivariate analysis ( $p>0.05$ ).

For local invasion to occur the basal membrane must be disrupted. MMPs are proteolytic enzymes which can degrade the structural elements of the extracellular matrix. This isplays an important role in invasion by extracellular matrix remodelling, liberating and activating growth factors, and cytokines, thereby facilitating tumor invasion ${ }^{40,16}$. Studies have shown that in many types of cancer the MMPs expression are elevated and associated with poor prognosis ${ }^{41,19,42}$. In breast cancer MMP-2 and MMP-9 are the main MMPs related with this type of cancer ${ }^{19}$.

In our study MMP-2 expression was positive in $13.6 \%$ of IDC and in DCIS cases with perfect positive correlation (cC = 1). MMP-9 was positive in $75.5 \%$ in IDC and in $74.5 \%$ in DCIS with statistically significant correlation $(p<0.01)$. Di et al. $(2005)^{21}$ and Lu et al. (2007) $)^{22}$ using polyclonal antibodies for immunohistochemistry analyzed only IDC and found positive values similar to ours $(72.3 \%$ and $62.7 \%$ respectively). When evaluating MMP-2 they found higher values of positivity $(68.7 \%$ and $58.6 \%$ respectively). Kohrmann et al. (2009) ${ }^{43}$ evaluated normal breast tissues and IDC specimens and found higher expression of MMP-2 and MMP-9 in the tumors.

When we evaluated only IDC we found a statistically significant positive correlation between aromatase and MMP-2 $(p=0.001)$ and between aromatase and MMP-9 $(p=0.034)$. Similar results were obtained by Di et al. (2005) and Lu et al. (2007) with $p<0.001^{21,22}$.

These results and others that show positive correlation between aromatase and MMP-2 and aromatase and MMP-9 increase the possibility that aromatase can elevate the invasion capacity of tumor cells by increasing the activity of MMP-2 and MMP-9. It is possible that with a higher expression of aromatase, there is a higher activity and action of MMPs for degrading the extracellular matrix and favoring disease progression.

When we evaluated only DCIS we found a statistically significant positive correlation between aromatase and MMP- 2 and MMP-9 and CD44 ( $p=0.030)$. The positive correlation between aromatase and MMP-2 in DCIS confirms the tendency that neoplasia, which shows aromatase expression, has higher invasion potential.

A melanoma study by Yu and Stamenkovic (2000) ${ }^{44}$ and a prostate study by Desai et al. (2007) ${ }^{26}$ showed a fundamental connection between CD44 and MMP-9, as the latter acts in degrading the basal membrane and initiates local invasion. Ours results showing a positive correlation between MMP-9 and CD44 $(p=0.030)$ corroborate findings by these authors and Peng et al. (2007) ${ }^{28}$ who observed MMP-9 and CD44 correlation in breast cancer cells. These results are an indication that CD44 acts as a docking site for MMP-9 and that formation of the CD44/MMP-9 complex on the cellular surface probably is necessary for MMP-9 action.

\section{Conclusion}

After analysis of our results we can conclude that aromatase from local breast tissue estrogen synthesis play an important role in breast carcinogenesis, influencing mainly MMP-2 and MMP-9 which are important participants in tumor invasion and their probable dependence of their conection with CD44 to act.

These results allow us to consider that use of aromatase inhibitors ( $\mathrm{Al}$ ) acts in the prevention and treatment of breast cancer not just because of reduction in blood and local concentration of estrogen but also because of the action on important pathways for tumor progression where the CD44/MMP-9 complex plays a fundamental role. It is possible that use of some substances which inhibit MMPs isolated or associated with Al, may be a promising target for researchers of breast cancer treatment.

\section{Conflict of interest: none}

\section{Resumo}

\section{A Interação entre aromatase, metalloproteinase 2, 9 e CD44 NO CÂNCER DE MAMA}

Objetivo. O objetivo desse estudo é verificar as expressões e correlações da aromatase, metalloproteinase 2 da matriz (MMP2), metalloproteinase 9 da matriz (MMP-9) e CD44 no carcinoma ductal in situ (CDIS) e carcinoma ductal infiltrativo (CDI) quando ambos estão presentes simultaneamente na mesma mama.

MÉtodos. Foram avaliados 110 casos pelo método de tissue microarray (TMA) e através da utilização de anticorpos policlonais antiaromatase, anticorpos monoclonais anti-MMP-2, anticorpos policlonais anti-MMP-9 e anticorpos monoclonais anti-CD44.

REsultados. A aromatase estava expressa de forma positiva no CDI e CDIS em 63 (57,3\%) e 60 (67\%) casos, respectivamente. A expressão de MMP-2 estava expressa de forma positiva em 15 (13,6\%) casos tanto no CDI, quanto no CDIS. A expressão da MMP-9 estava expressa de forma positiva em 83 $(75,5 \%)$ e $82(74,5 \%)$ casos de CDI e CDIS, respectivamente. A expressão de CD44 estava expressa de forma positiva em $49(44,5 \%)$ e 48 (42,6\%) casos de CDI e CDIS, respectivamente. Todos eles apresentando alta correlação $(p<0,001)$. $\mathrm{Na}$ avaliação de correlação foi encontrada correlação positiva estatisticamente significante no CDI entre aromatase e MMP-2 $(p<0,01)$ e entre aromatase e MMP-9 $(p=0,034)$. Nos casos de CDIS houve correlação positiva estatisticamente significante entre aromatase e MMP-2 $(p<0,001)$ e entre CD44 e MMP-9 $(p=0,030)$.

Conclusão. Após analisarmos os resultados de nosso estudo, podemos concluir que a aromatase, através da síntese de estrogênio local no tecido mamário, desempenha importante papel na carcinogênese mamária, principalmente influenciando a atuação da MMP-2 e da MMP-9, grandes responsáveis pela invasão celular tumoral que, por sua vez, provavelmente dependem de sua ligação a CD44 para poder desempenhar suas funções. [Rev Assoc Med Bras 2010; 56(4): 472-7]

Unitermos: Aromatase. Metaloproteinase 2 da matriz. Metaloproteinase 9 da matriz. Antígenos CD44. Carcinoma ductal de mama. 


\section{REFERENCES}

1. Henderson IC, Canellos GP. Cancer of the breast: the past decade. N Engl J Med. 1990;302:17-30.

2. Pasqualini JR, Chetrite GS. Recent insight on the control of enzymes involved in estrogen formation and transformation in human breast cancer. J Steroid Biochem Mol Biol. 2005;93:221-36.

3. Russo J, Russo IH. The role of estrogen in the initiation of breast cancer. J Steroid Biochem Mol Biol. 2006;102:89-96.

4. American Cancer Society. Breast cancer facts \& figures 2007-2008. Atlanta: American Cancer Society, Inc. Available from: http://www.cancer.gov.

5. Russo J, Hasan Lareef M, Balogh G, Guo S, Russo IH. Oestrogen and its metabolites are carcinogenic agents in human breast epithelial cells. J Steroid Biochem Mol Biol. 2003;87:1-25.

6. Simpson ER. Sources of estrogen and their importance. J Steroid Biochem Mol Biol. 2003;86:225-30.

7. Subramanian A, Salhab M, Mokbel K. Oestrogen producing enzymes and mammary carcinogenesis: a review. Breast Cancer Res Treat. 2008;111:191-202.

8. Chetrite GS, Cortes-Prieto J, Philippe JC, Wright F, Pasqualini JR. Comparison of estrogen concentrations, estrone sulfatase and aromatase activities in normal, and in cancerous, human breast tissues. J Steroid Biochem Mol Biol. 2000;72:23-7.

9. Prichard RS, Hill AD, Dijkstra B, McDermott EW, OHiggins NJ. The prevention of breast cancer. Br J Surg. 2003;90:772-83.

10. Suzuki T, Miki Y, Nakamura Y, Moriya T, Ito K, Ohuchi N, et al. Sex steroid-producing enzymes in human breast cancer. Endocr Relat Cancer. 2005; 12:701-20.

11. Bulun SE, Takayama K, Suzuki T, Sasano H, Yilmaz B, Sebastian S. Organization of the human aromatase p450 (CYP19) gene. Semin Reprod Med 2004;22:5-9.

12. Hudelist G, WülWng P, Kersting C, Burger H, Mattsson B, Czerwenka K, et al. Expression of aromatase and estrogen sulfotransferase in preinvasive and invasive breast câncer. J Cancer Res Clin Oncol. 2008;134:67-73.

13. Nagase H, Visse R, Murphy G. Structure and function of matrix metalloproteinases and TIMPs. Cardiovasc Res. 2006;69:562-73.

14. Page-McCaw A, Ewald AJ, Werb Z. Matrix metalloproteinases and the regulation of tissue remodelling. Nat Rev Mol Cell Biol. 2007;8:211-33.

15. Puente XS, López-Otín C. A genomic analysis of rat proteases and protease inhibitors. Genome Res. 2004;14:609-22.

16. Sternlicht MD, Werb Z. How matrix metalloproteinases regulate cell behavior. Annu Rev Cell Dev Biol. 2001;17:463-516.

17. Iwasaki M, Nishikawa A, Fujimoto T, Akutagawa N, Manase K, Endo T, et al. Anti-invasive effect of $\mathrm{MMI}-166$ new selective matrix metalloproteinase inhibitor, in cervical carcinoma cell lines. Gynecol Oncol. 2002;85:103-7.

18. Kato Y, Yamashita T, Ishikawa M. Relationship between expression of matrix metalloproteinase-2 and matrix metalloproteinase- 9 and invasion ability of cervical cancer cells. Oncol Rep. 2002;9:565-9.

19. Li HC, Cao DC, Liu Y, Hou YF, Wu J, Lu JS. Prognostic value of matrix metalloproteinases (MMP-2 and MMP-9) in patients with lymph node-negative breast carcinoma. Breast Cancer Res Treat. 2004;88:75-85.

20. Vizoso FJ, González LO, Corte MD, Rodríguez JC, Vasquez J, Lamelas ML, et al. Study of matrix metalloproteinases and their inhibitors in breast cancer. Br J Cancer. 2007;96:903-11.

21. Di GH, Lu JS, Song CG, Li HC, Shen ZZ, Shao ZM. Over expression of aromatase protein is highly related to MMPs levels in human breast carcinomas. J Exp Clin Cancer Res. 2005;24:601-7.

22. Lu J, Li H, Cao D, Di G, Wu J, Sheng K, et al. Clinical significance of aromatase protein expression in axillary node negative breast cancer. J Cancer Res Clin Oncol. 2007;133:401-9.

23. Cichy J, Puré E. The liberation of CD44. J Cell Biol. 2003;161:839-43.

24. Okamoto I, Tsuiki H, Kenyon LC, Goldwin AK, Emlet DR, Holgado-Madruga M, et al. Proteolytic cleavage of the CD44 adhesion molecule in multiple human tumors. Am J Pathol. 2002;160:441-7.

25. Abraham BK, Fritz P, McClellan M, Hauptvogel P, Athelogou M, Brauch H. Prevalence of CD44/CD24-/low cells in breast cancer may not be associated with clinical outcome but may favor distant metastasis. Clin Cancer Res. 2005;11:1154-9.

26. Desai B, Rogers MJ, Chellaiah MA. Mechanisms of osteopontin and CD44 as metastatic principles in prostate cancer cells. Mol Cancer. 2007;6:18.

27. Samanna V, Ma T, Mak TW, Rogers M, Chellaiah MA. Actin polymerization modulates CD44 surface expression, MMP-9 activation, and osteoclast function. J Cell Physiol. 2007;213:710-20.

28. Peng ST, Su CH, Kuo CC, Shaw CF, Wang HS. CD44 crosslinking-mediated matrix metalloproteinase- 9 relocation in breast tumor cells leads to enhanced metastasis.Int J Oncol. 2007;31:1119-26.

29. Dabbs DJ. Ductal carcinoma of breast: nuclear grade as a predictor of S-phase fraction. Hum Pathol. 1993;24:652-6.

30. Elston CW, Ellis IO. Pathological prognostic factors in breast cancer. I. The value of histological grade in breast cancer: experience from a large study with long-term follow-up. Histopathology. 1991;19:403-10.

31. Oliveira VM, Piato S, Silva MA. Correlation of cyclooxygenase-2 and aromatase immunohistochemical expression in invasive ductal carcinoma, ductal carcinoma in situ, and adjacent normal epithelium. Breast Cancer Res Treat. 2006;95:235-41.

32. Ellis MJ, Tao Y, Young $O$, White S, Proia AD, Murray J, Renshaw L, et al. Estrogen-independent proliferation is present in estrogen-receptor HER2positive primary breast cancer after neoadjuvant letrozole. J Clin Oncol. 2006;24:3019-25.

33. Ristimäki A, Sivula A, Lundin J. Prognostic significance of elevated cyclooxygenase-2 expression in breast cancer. Cancer Res. 2002;62:632-5.

34. Bernard R. Fundamentals of biostatistics. $2^{\text {nd }}$ ed. Boston: Buxbury Press; 1986.

35. Shibuya R, Suzuki T, Miki Y, Yoshida K, Moriya T, Ono K, et al. Intratumoral concentration of sex steroids and expression of sex steroid-producing enzymes in ductal carcinoma in situ of human breast. Endocr Relat Cancer. 2008; 15:113-24.

36. Oliveira VM, Ribeiro LS, Rossi LM, Silva MA, Aldrigui JM, Bagnoli F, et al. Aromatase expression in invasive and in situ ductal carcinoma present in the same breast. Rev Assoc Med Bras. 2009 ;55:651-5.

37. Díaz-Cruz ES, Shapiro CL, Brueggemeier RW. Cyclooxygenase inhibitors suppress aromatase expression and activity in breast cancer cells. J Clin Endocrinol Metab. 2005;90:2563-70.

38. Silva MC, Rowlands MG, Dowsett M, Gusterson B, Mckinna JA, Fryatt I, et al. Intratumoral aromatase as a prognostic factor in human breast carcinoma. Cancer Res. 1989;49:2588-91.

39. Eppenberger-Castori S, Kueng W, Benz C, Caduff R, Varga Z, Bannwarrt F, et al. Prognostic and predictive significance of ErbB-2 breast tumor levels measured by enzyme immunoassay. J Clin Oncol. 2001;19:645-56.

40. Ellerbroek SM, Stack MS. Membrane associated matrix metalloproteinases in metastasis. Bioessays. 1999;21:940-9.

41. Curran S, Dundas SR, Buxton J, Leeman MF, Ramsay R, Murray GI. Matrix metalloproteinase/tissue inhibitors of matrix metalloproteinase phenotype identifies poor prognosis colorectal cancers. Clin Cancer Res. 2004;10:8229-34.

42. Pellikainen JM, Ropponen KM, Kataja VV, Kellokoski JK, Eskelinen MJ, Kosma VM. Expression of matrix metalloproteinase (MMP)-2 and MMP-9 in breast cancer with a special reference to activator protein-2, HER2, and prognosis. Clin Cancer Res. 2004;10:7621-8.

43. Köhrmann A, Kammerer U, Kapp M, Dietl J, Anacker J. Expression of matrix metalloproteinases (MMPs) in primary human breast cancer and breast cancer cell lines: new findings and review of the literature. BMC Cancer. $2009 ; 16: 188$.

44. Yu Q, Stamenkovic I. Cell surface-localized matrix metalloproteinase-9 proteolytically activates TGF-beta and promotes tumor invasion and angiogenesis. Genes Dev. 2000;14:163-76.

Artigo recebido: $26 / 04 / 10$

Aceito para publicação: 23/05/10 